\title{
Improvements in copper electrowinning at Tenke Fungurume Mining Company
}

\author{
by S. Sandoval*, N. Goel*, A. Luzanga*, and 0. Tshifungat*
}

\section{Synopsis}

Tenke Fungurume Mining Company (TFM), located in Katanga Province, Democratic Republic of Congo (DRC), began production of copper cathode and cobalt hydroxide in March 2009. Copper production capacity was 115000 t/a utilizing a semi-autogenous grinding, agitated leach, countercurrent decantation process followed by solvent extraction and electrowinning (SX-EW). Cobalt production capacity (as cobalt hydroxide) was $8000 \mathrm{t} / \mathrm{a}$ utilizing a three-stage purification/precipitation process treating raffinate from the copper SX-EW process. Recently a phase II expansion was completed, in which copper electrowinning capacity was doubled and four stages were added to the SX plant. Corresponding enhancements were made to mining, milling, and processing to bring production to $195 \mathrm{kt} / \mathrm{a}$ copper and $15 \mathrm{kt} / \mathrm{a}$ cobalt. An additional sulphuric acid plant is currently being constructed, adding $1400 \mathrm{t} / \mathrm{d}$ sulphuric acid to bring total acid production to $2250 \mathrm{t} / \mathrm{d}$ for use in leaching at TFM.

Initial copper electrowinning results were satisfactory, but cathode quality and current efficiency decreased as copper production increased. The Freeport-McMoRan (FCX) Technology Centre and TFM personnel began operation of two bench-scale copper electrowinning cells in the tankhouse to diagnose chemistry effects on the cathode and anode. The results indicated an excellent electrolyte chemistry, producing finely crystalline copper at $430 \mathrm{~A} / \mathrm{m}^{2}$ current density with $98 \%$ current efficiency. Attention next turned to the physical factors of the electrowinning cells, including electrode insulator geometry and performance. A demonstration cell was selected in the tankhouse and was operated with varying cathode and anode insulator geometries. Operation of the demonstration cell with a three-side cathode edge strip, A-style anode insulators, and an improved cell furniture design increased current efficiency from $77 \%$ to $89 \%$ at 400 $\mathrm{A} / \mathrm{m}^{2}$ current density. Cathode quality improved correspondingly. TFM is now operating at $92 \%$ current efficiency.

\section{Keywords}

copper, cobalt, electrowinning, cathode quality. as electrowon cathode and cobalt as cobalt hydroxide.

Production began in March of 2009. A process flow diagram is shown in Figure 1. Surface-mined ore reported to a single-stage semi-autogenous grinding (SAG) mill at a rate of 8000 t/day. The thickened pulp was then subjected to an agitated sulphuric acid leach at atmospheric pressure. Sulphur dioxide gas was introduced in the agitated leach to reduce $\mathrm{Co}^{3+}$ to $\mathrm{Co}^{2+}$ in the leach liquor. The leach discharge thickener overflow produced high-grade pregnant leach solution (HG PLS) containing about $13 \mathrm{~g} / \mathrm{L}$ copper. The HG PLS was sent to solvent extraction-electrowinning (SX-EW) for recovery of the copper at a rate of $115000 \mathrm{t}$ copper per year. The HG raffinate from SX, containing about $20 \mathrm{~g} / \mathrm{L}$ sulphuric acid, was returned to leaching for utilization of the acid.

The leach discharge thickener underflow was processed by countercurrent decantation (CCD) to produce a low-grade pregnant leach solution (LG PLS) that contained about $6 \mathrm{~g} / \mathrm{L}$ copper. Copper was recovered from the LG PLS by SX-EW and the raffinate, which contained about $2 \mathrm{~g} / \mathrm{L}$ cobalt, was sent to the cobalt recovery circuit. This circuit first oxidized $\mathrm{Fe}^{2+}$ to $\mathrm{Fe}^{3+}$ and $\mathrm{Mn}^{2+}$ to $\mathrm{Mn}^{4+}$ using a mixture of sulphur dioxide and air, then the iron, manganese, and aluminium were precipitated by limestone addition. In a second precipitation stage, residual copper was precipitated using lime addition. This led to the third stage of the cobalt recovery circuit where cobalt hydroxide was precipitated using magnesium oxide. The resultant cobalt hydroxide cake could then be bagged either moist or dry for shipment at a rate of $8000 \mathrm{t}$ cobalt per year.

* Tenke Fungurume Mining Company (an Affiliate of Freeport-McMoRan Inc)., Democratic Republic of Congo.

(C) The Southern African Institute of Mining and Metallurgy, 2016. ISSN 2225-6253. This paper was first presented at the, Copper Cobalt Africa Conference, 6-8 July 2015, Avani Victoria Falls Hotel, Victoria Falls, Livingstone, Zambia. 


\section{Improvements in copper electrowinning at Tenke Fungurume Mining Company}

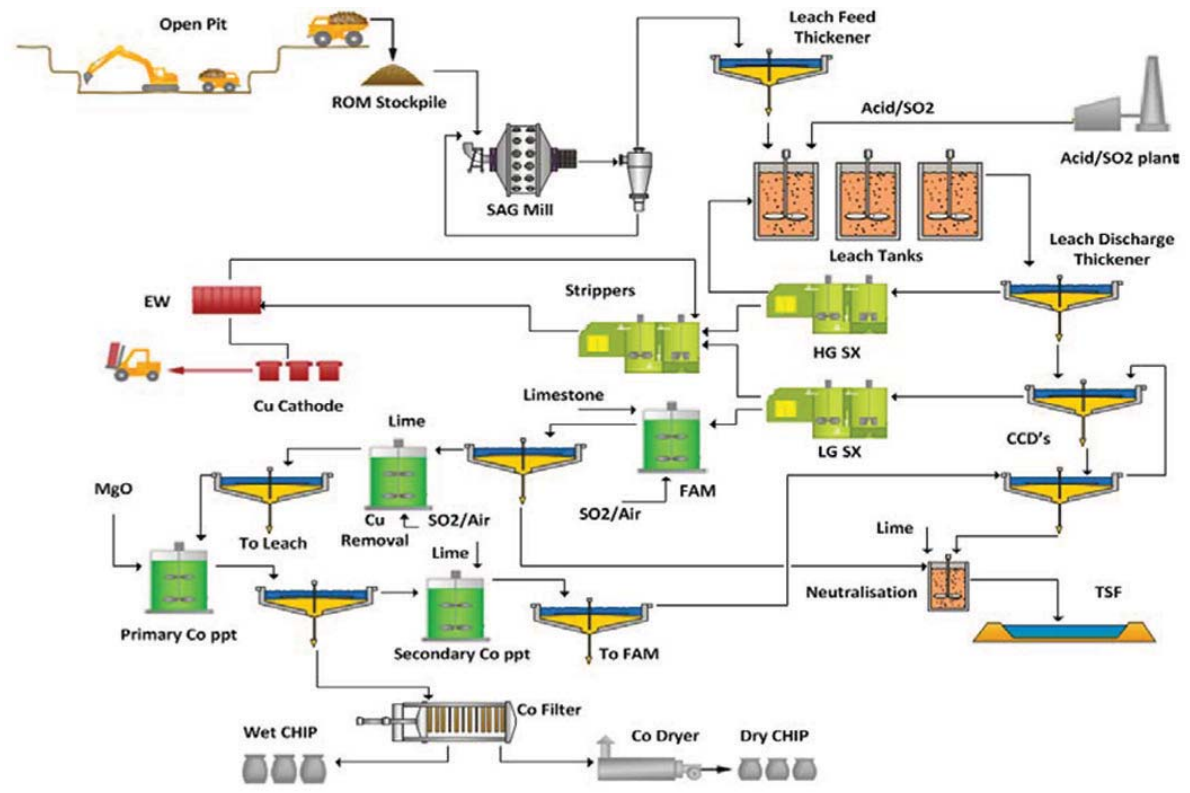

Figure 1-TFM process flow diagram

This paper summarizes the history of TFM developments and also presents the improvements that have been implemented in the production process since start-up. Steps to improve copper cathode quality are also described.

\section{History}

Exploration of the TFM deposits began as early as 1917 and continued intermittently through 1970 . The first drilling was conducted in 1918 by Union Minière de Haut Katanga, but no mining ensued at that time. In 1970, the Societé Minière de Tenke Fungurume and Gécamines were awarded the concessions and began to study the feasibility of constructing a mine. Some infrastructure, including access roads, was constructed. This work was abandoned in 1976 because of the falling copper price, a delay in the construction of a power line, and a deteriorating political and social situation in DRC.

In 1996, TFM was established and the concessions transferred from Gécamines. In 1998, TFM and Lundin Holdings began a feasibility study, but the work was abandoned in 1998 due to the outbreak of a civil war in DRC and the study was left unfinished. In 1998, TFM concluded an option agreement with BHP Billiton that would allow BHP to acquire a controlling interest in TFM. This option was transferred to Phelps Dodge in 2002. In 2003, Phelps Dodge commissioned a study for processing the Kwatebala orebody to produce 30000 t/a copper and 1800 t/a cobalt. Studies continued to progress until in 2006 the plant capacity was set at 8000 td of ore throughput to produce 115000 t/a copper and 8000 t/a cobalt. The initial mine life expectancy was 20 years. Construction of the project began in 2006 and first copper and cobalt were produced in 2009. In 2007 FreeportMcMoRan Inc. acquired Phelps Dodge.

\section{TFM developments}

\section{Phase I}

Analysis of TFM ore showed that the major copper oxide mineral was malachite. The major cobalt oxide mineral was heterogenite. The gangue matrix consisted of quartz, muscovite (mica), chlorite, tourmaline, and dolomite, with minor concentrations of iron oxides/hydroxides, clays, and feldspars. Metallurgical development of the extraction process began with batch and semi-continuous test work conducted at Freeport-McMoRan's Technology Centre in Safford, AZ and at Hazen Research Centre in Denver, CO. In 2006, three integrated pilot plant campaigns were completed at Hazen, as shown in Figure 2.

Results from the metallurgical testing were used as a basis for inputs to the process design criteria and to the mass and energy balances. A detailed plant model was developed using METSIM.

Construction of the plant required a little over two years and the first copper and cobalt were produced in March 2009.

\section{Copper quality}

The Phase I tankhouse contained four banks of 70 cells each for a total of 280 cells. Each cell contained 66 cathodes with approximately $2.4 \mathrm{~m}^{2}$ of plating surface per cathode. Two rectifiers per tankhouse side provided a maximum amperage of $66 \mathrm{kA}$ per cell, or a maximum current density of $420 \mathrm{~A} / \mathrm{m}^{2}$. The tankhouse utilized three Metso cathode stripping machines at a six-day harvest cycle. The TFM tankhouse is displayed in Figure 3.

Also displayed in Figure 3 are two bench-scale copper electrowinning cells operated in the tankhouse. As tankhouse amperage increased, current efficiency decreased and cathode quality also suffered. The FCX Technology Centre and TFM personnel began operation of two bench-scale copper electrowinning cells to demonstrate the current efficiency and copper quality achievable using TFM electrolyte. The benchcells by design provide a perfect electrowinning environment. Key parameters included excellent current distribution, electrode contact system, electrode straightness and alignment, and electrolyte distribution. Perfect conditions are 


\section{Improvements in copper electrowinning at Tenke Fungurume Mining Company}
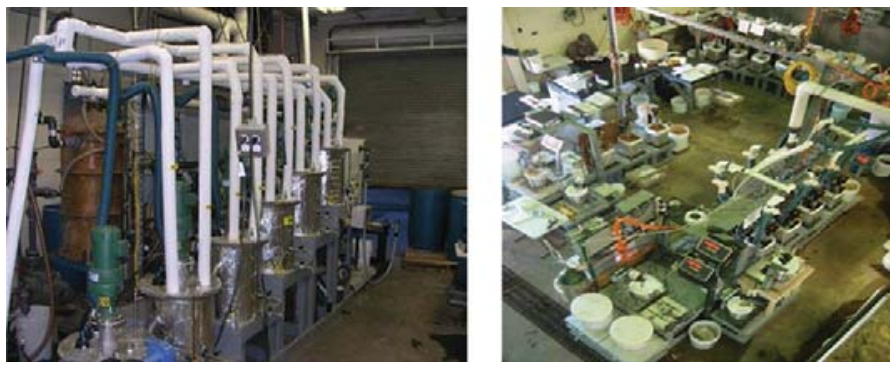

Figure 2-Pilot plant campaigns at Hazen Research Centre
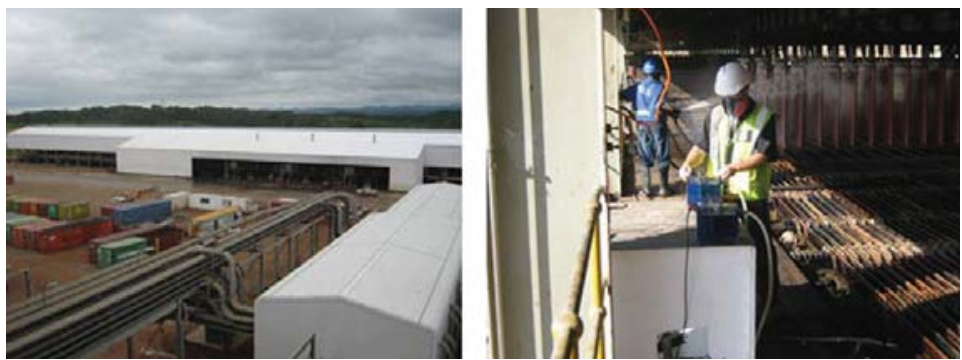

Figure 3-TFM copper electrowinning tankhouse, and two bench-cells operated in the tankhouse

not obtained in commercial cells because of scale-up imperfections. However, the bench-cells provide a useful benchmark.

The bench-cells utilized stainless steel cathodes and standard lead anodes. Operating current density was $430 \mathrm{~A} / \mathrm{m}^{2}$. Four bench-cell tests were completed to evaluate cathode deposits with 1, 2, 3, and 4 days of plating time. Current efficiency results are shown in Table I. Typical cathodes harvested from the bench-cells are shown in Figure 4.

The TFM electrolyte was unique in that in contained $43 \mathrm{~g} / \mathrm{L} \mathrm{Cu}, 1 \mathrm{~g} / \mathrm{L} \mathrm{Co}$, and $1 \mathrm{~g} / \mathrm{L}$ Fe. The cathodes exhibited excellent apparent deposit morphology and current efficiency was $98 \%$. The deposits were smooth and finely crystalline. The bench-cell testing demonstrated excellent current efficiency, excellent cathode quality, and good lead anode performance. Attention next turned to the physical factors of the TFM electrowinning cells, including electrode insulator geometry and performance. A demonstration cell was selected in the tankhouse and was operated with varying cathode and anode insulator geometries. Three demonstration tests were performed as shown in Table II.

Included in the demonstration cell testing was an improved cell furniture design, as shown in Figure 5. Contact clearance was an issue in the old furniture, creating electrode no-contacts because the hanger bar touched the cap block and not the copper conductor bar. This affected current distribution within the cell and contributed to short-circuits.

Experience at the El Abra tankhouse (FMI's El Abra Operations, Calama, Chile) showed that the A-style bottom corner anode insulators provided strong alignment of anodes and cathodes, which would be a significant benefit because TFM cathodes utilized a 1.2-m long cathode plating area. It became of interest to test the A-style anode insulator using

\begin{tabular}{|c|c|}
\hline \multicolumn{2}{|c|}{$\begin{array}{l}\text { Table I } \\
\text { Current efficiency of bench-cell tests using TFM } \\
\text { electrolyte }\end{array}$} \\
\hline Days of plating & Current efficiency (\%) \\
\hline $\begin{array}{l}1 \\
2 \\
3 \\
4\end{array}$ & $\begin{array}{l}98 \\
98 \\
97 \\
98\end{array}$ \\
\hline
\end{tabular}
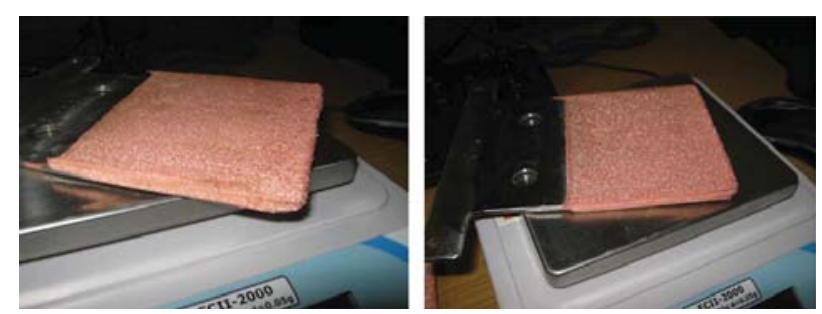

Figure 4-Bench-cell cathodes produced using TFM electrolyte at $430 \mathrm{~A} / \mathrm{m}^{2}$

Table II

Tankhouse demonstration cell tests

\begin{tabular}{|l|c|c|}
\hline $\begin{array}{l}\text { Demonstration } \\
\text { test }\end{array}$ & Cathode insulator & Anode insulator \\
\hline 1 & Single-side edge strip & Blue star \\
\hline 2 & 3-side edge strip & Blue star and hairpin \\
\hline 3 & 3-side edge strip & $\begin{array}{c}\text { A-style bottom corners } \\
\text { and blue star }\end{array}$ \\
\hline
\end{tabular}




\section{Improvements in copper electrowinning at Tenke Fungurume Mining Company}
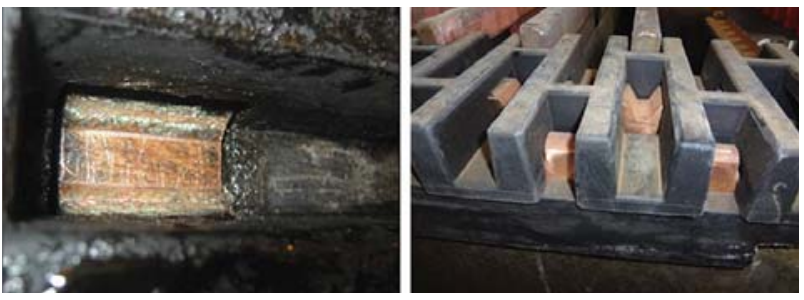

Figure 5-Old cell furniture (right), showing poor clearance between cap block and contact. On left is new cell furniture with robust contact clearance

TFM anodes in demonstration test 3 . The single-side edge strips in use on TFM cathodes were also causing difficulty in the tankhouse because the bottom corners would separate from the stainless steel blanks, exposing the cathodes to nodulation during plating, a significant problem for LME visual grading of cathode and for formation of short-circuits. It became of interest to evaluate the Morenci (FMI's Morenci Operations, Morenci, Arizona) three-side cathode edge strip for TFM cathodes because this would correct the nodulation problem and would also cover the cathode bottom V-groove, which tended to cut off anode insulators during the harvest cycle. Figure 6 displays the A-style anode insulator and the three-side cathode edge strip on TFM electrodes. Typical electrolyte conditions during the tankhouse demonstration cell testing were $57^{\circ} \mathrm{C}$ electrolyte temperature, $0.12 \mathrm{~m} / 3 / \mathrm{h} / \mathrm{m}^{2}$ electrolyte flow rate, and 400 to $410 \mathrm{~A} / \mathrm{m}^{2}$ current density. Commercial electrolyte measured $43 \mathrm{~g} / \mathrm{L}$ copper. Results of the demonstration cell testing are displayed in Table III.

Demonstration test 3 was superior in both current efficiency and visual quality of product, increasing current efficiency from $77 \%$ to $89 \%$. The A-style anode insulators and three-side cathode edge strips provided strong alignment of anodes and cathodes, a significant benefit at current density over $400 \mathrm{~A} / \mathrm{m}^{2}$.

The insulator geometry of demonstration test 3 was installed in the TFM tankhouse along with the new furniture design. Tankhouse results are displayed in Figures 7 and 8. Current efficiency was increased by $12 \%$ and cathode quality was reversed, decreasing off-grade copper to below $5 \%$. Copper production increased from 7.2 to $8.9 \mathrm{t}$ per cell over days. To help sustain the improved performance, single carts (Figure 9) were implemented in the tankhouse for shortcircuit correction. Up to four single carts per tankhouse side were operated daily. At present the TFM tankhouse is operating at $92 \%$ current efficiency.

\section{Phase II}

Analysis of the Phase I production plant identified limiting process steps or bottlenecks in the circuit. The bottlenecks resided primarily in the milling, SX-EW, and cobalt hydroxide handling portions of the plant. In addition, electrolyte temperature was deemed too high at $57^{\circ} \mathrm{C}$. A cooling tower was needed to eliminate overheating of the tankhouse. In 2011, Freeport-McMoRan commissioned a Phase II feasibility study to increase plant capacity to $14000 \mathrm{t}$ ore per day for production of $195 \mathrm{kt}$ copper and $15000 \mathrm{kt}$ cobalt per annum,

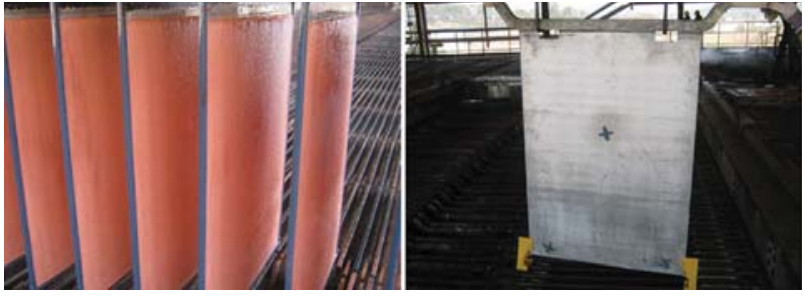

Figure 6-A-style bottom corner and blue star insulators on anodes, three-side edge strip on cathodes

\begin{tabular}{|c|c|c|c|}
\hline \multicolumn{4}{|c|}{$\begin{array}{l}\text { Summary of TFM tankhouse demonstration cell } \\
\text { results }\end{array}$} \\
\hline $\begin{array}{l}\text { Demonstration } \\
\text { test }\end{array}$ & $\begin{array}{c}\text { Average current } \\
\text { density }\left(\mathrm{A} / \mathrm{m}^{2}\right)\end{array}$ & $\begin{array}{c}\text { Current } \\
\text { efficiency (\%) }\end{array}$ & $\begin{array}{c}\text { Grade of copper } \\
\text { produced }\end{array}$ \\
\hline $\begin{array}{l}1 \\
2 \\
3\end{array}$ & $\begin{array}{l}410 \\
410 \\
400\end{array}$ & $\begin{array}{l}75 \\
77 \\
89\end{array}$ & $\begin{array}{l}\text { High grade } \\
\text { High grade } \\
\text { High grade }\end{array}$ \\
\hline
\end{tabular}

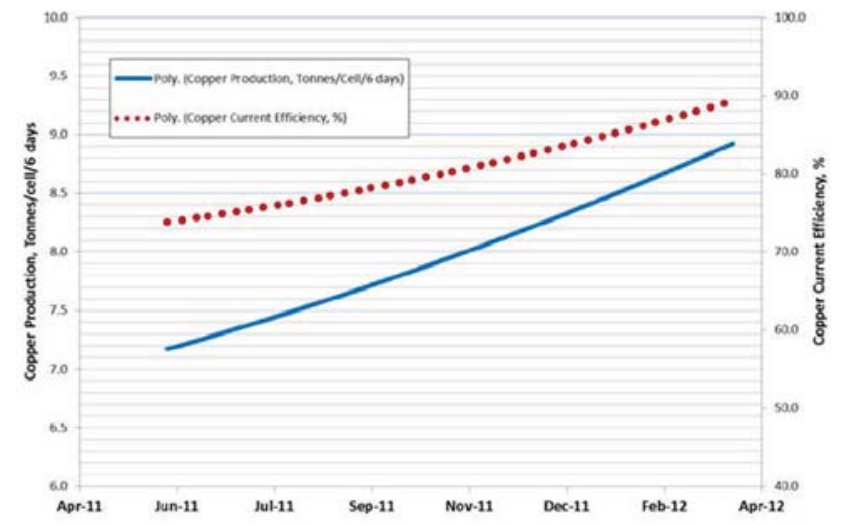

Figure 7-Increase in current efficiency and production with transition of tankhouse

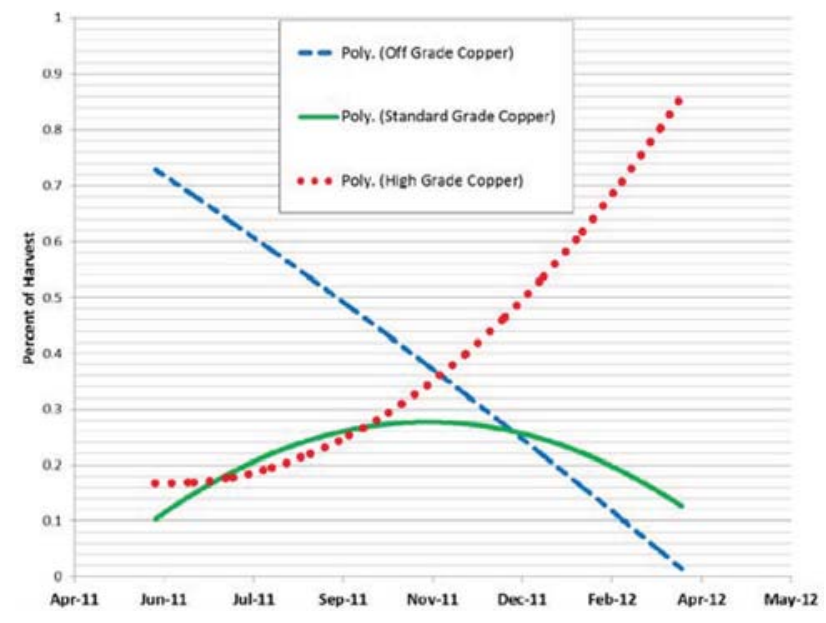

Figure 8-Reversal of cathode quality with transition of tankhouse 


\section{Improvements in copper electrowinning at Tenke Fungurume Mining Company}

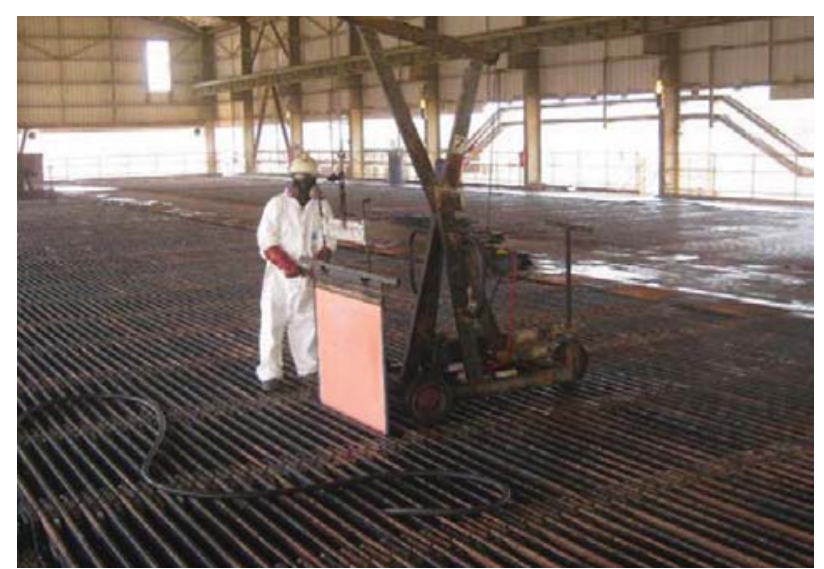

Figure 9-Single-pull cart used to correct short-circuits in tankhouse

representing a $70 \%$ increase in copper production and an $87 \%$ increase in cobalt production from the original capacities. In that same year, the Phase II expansion began and was completed in 2012. The major addition was a second electrowinning tankhouse with 280 new cells that doubled copper electrowinning capacity to a total of 560 cells. Four SX mixer-settlers were added to the high-grade circuit along with four garnet/anthracite-rich electrolyte filters, increasing the total number of filters to eight.

On the front end of the plant a pebble crusher and a jaw crusher were added to the SAG mill circuit. In the cobalt process, the cobalt hydroxide handling system was expanded. Two additional sulphur dioxide burners were added for increased sulphur dioxide addition to the agitated leach. Figures 10 and 11 show the increase in copper and cobalt production achieved in Phase II. Table IV displays TFM copper and cobalt production in 2013 and 2014.

\section{Present}

To become less dependent on third-party sulphuric acid for leaching, TFM is now constructing a new $1400 \mathrm{t} / \mathrm{d}$ sulphuric acid plant to bring total site acid production to $2250 \mathrm{t} / \mathrm{d}$. The new plant is targeted to begin operation in 2015. Currently, TFM is producing $850 \mathrm{t} / \mathrm{d}$ sulphuric acid for leaching. In addition, the site operates a total of five separate sulphur burners to produce sulphur dioxide, two at $60 \mathrm{t} / \mathrm{d}$ sulphur dioxide and three at $50 \mathrm{t} / \mathrm{d}$, for use as reagent in the agitated leach.

By the 2018 to 2020 time frame, production from leaching of oxides is expected to begin to decline. Planning is now underway for the processing and treatment of mixed sulphide ores at TFM.

\section{Summary}

Tenke Fungurume Mining Company, in the Katanga Province of DRC, has developed through two phases into a major copper and cobalt producer with a nameplate capacity of $195 \mathrm{kt} / \mathrm{a}$ copper and $15000 \mathrm{kt} / \mathrm{a}$ cobalt. Electrowinning current efficiency and copper quality increased dramatically with optimization of the cathode and anode insulator

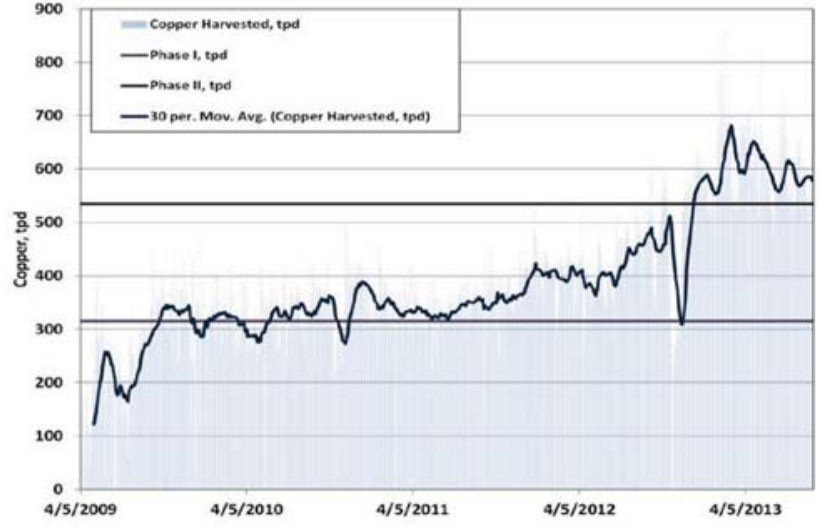

Figure 10-Phase II copper production

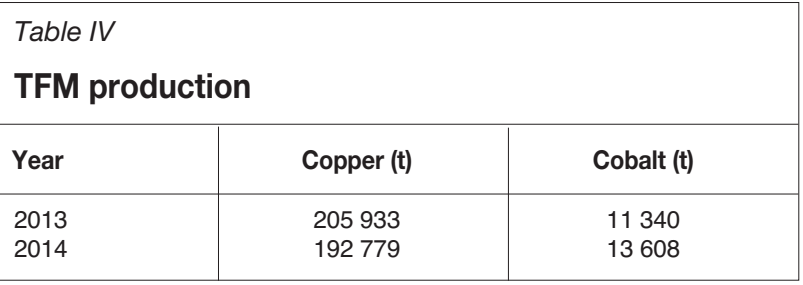

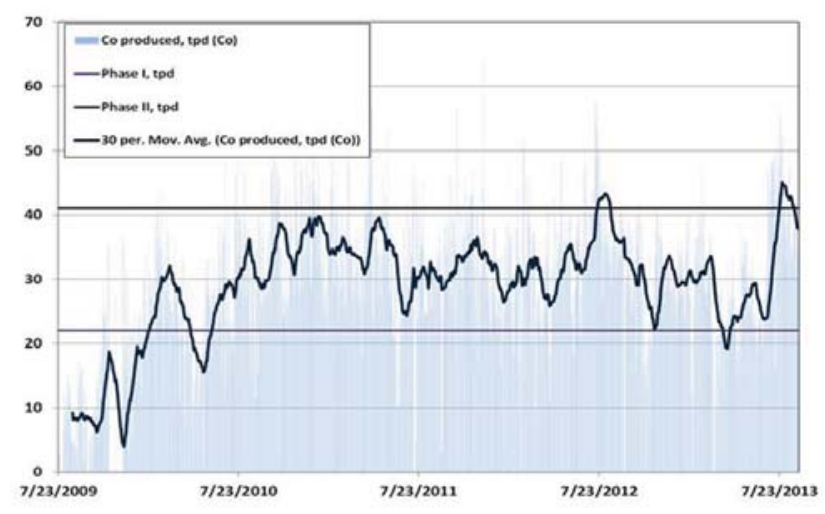

Figure 11-Phase II cobalt production

geometry and improvements in the electrowinning cell furniture. Currently the plant is operating at $92 \%$ current efficiency and greater than 95\% high-grade copper

Phases I and II progressed from integrated pilot-plant campaigns to plant construction beginning in 2006. Debottlenecking of the Phase I installation led to a doubling of electrowinning capacity in Phase II with a total of 560 electrowinning cells.

Currently a new sulphuric acid plant is being constructed on site that will increase sulphuric acid production from 850 to $2250 \mathrm{t} / \mathrm{d}$. Looking to the future, attention is now turning to plans to process mixed sulphides beginning in the 2020 time frame. Expectation of mine life now exceeds 40 years. 


\section{The $360^{\circ}$ Safety Solution}

Key benefits

- Proven proximity detection technology that sets new standards for workplace safety and facilitates 'zero harm' objectives.

- Improve operator situational awareness and reduce the incidence of injury.

- Fully configurable and adaptable to site-specific requirements.

- Real-time and historical reporting on interactions, near misses and system health.

- Supported worldwide by expert GE Mining teams.

- Effective, reliable and intuitive operation.

- Whole of mine solution:

OEM independent Stand-alone system Low "total cost of ownership"

- Proven in use over 10 years and 200 million hours of operation.
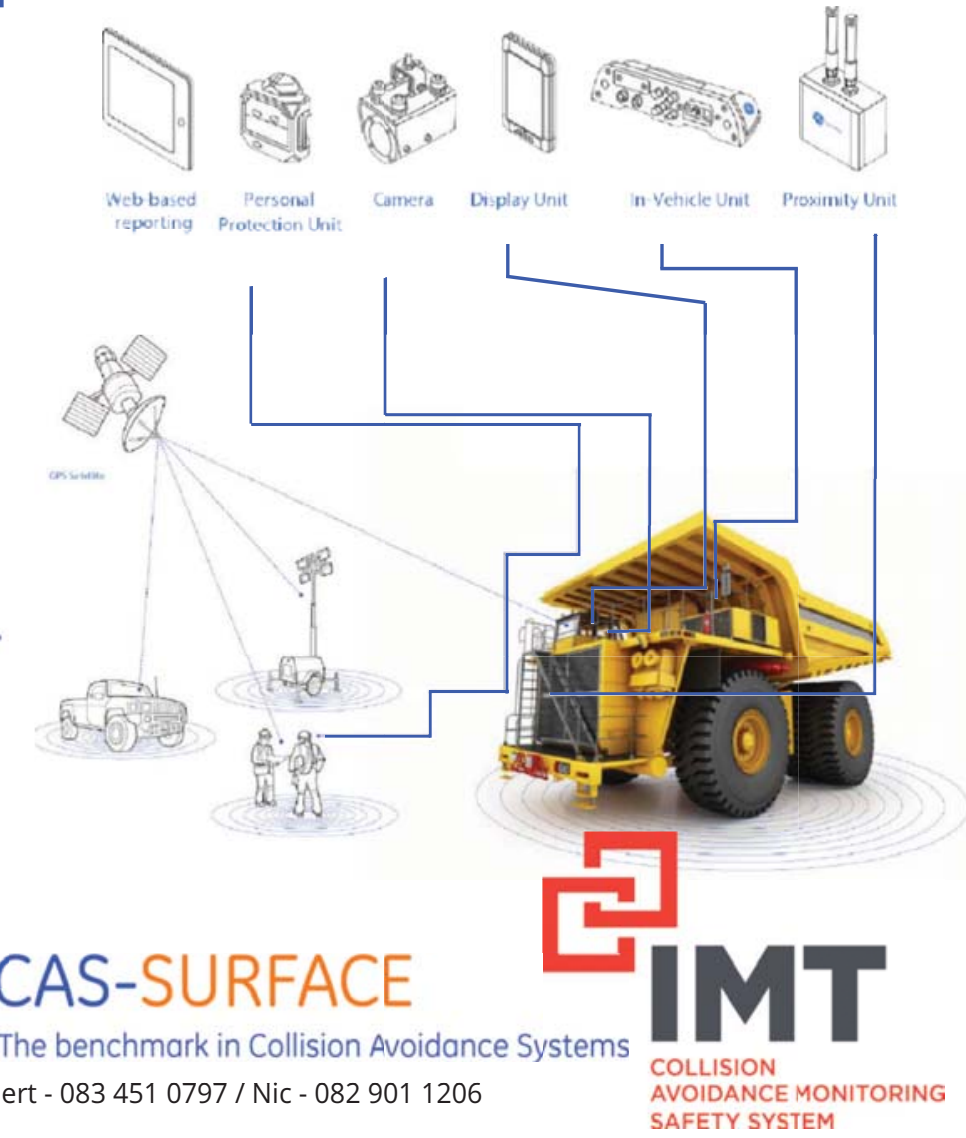

Witbank Wihan Brits - 0818501150 | Kuruman \& Kathu Leon Jordaan - 0824526459 | Rustenburg Stefan van Wyk - 0609710408 